\title{
No longer "the economy stupid": how muddled economics contributed to a chaotic Brexit
}

Iain BEGG, European Institute, London School of Economics

\begin{abstract}
The Faustian bargain at the heart of Brexit can be portrayed as a trade-off between enhanced control and economic benefits. Most commentators expect the UK economy to take some sort of hit from leaving the UK, but in the words of one prominent 'leave' supporter, it would be a 'price worth paying', to regain control over decision-making. ${ }^{1}$ For convinced Brexiteers, a UK unshackled from the EU will rapidly transform itself to be able to take advantage of opportunities in emerging markets and other dynamic parts of the global economy, while 'remainers' see distancing the UK from its largest market as an egregious act of self-harm. Both sides have been culpable of misleading statements. Similar dissembling occurred in relation to the public finances. The article explores how competing, poorly understood and often incoherent interpretations of economic propositions fed into Brexit, leading to misguided policy decisions and confusion in the debates around how to reset the UK's economic relationship with the EU.
\end{abstract}

\section{Key words}

Brexit policy failures

Economics of Brexit

No deal Brexit

Cost of Brexit

UK trade

\section{Introduction}

More than three years after the 2016 referendum, indecision and lack of direction have raised a plethora of questions about not only the UK's future economic model (Rosamond, 2019), but also the salience of economic assessments in a decision of such magnitude. Consequently, the received wisdom encapsulated in the phrase "it's the economy stupid" seems to have lost much of its resonance, raising doubts about the influence of political economy considerations in a matter of such significance to voters.

\footnotetext{
${ }^{1}$ https://www.politicshome.com/news/europe/eu-institutions/news/73963/arron-banks-\%C2\%A34300-lossprice-worth-paying-brexit
} 
Even so, Brexit is undeniably one of the biggest economic policy challenges of recent decades, for three main reasons. First, it will be a rare example of voluntary economic 'dis'integration, perhaps even unique insofar as it will be a large, advanced economy separating itself from a long-established economic partnership. The 'velvet' divorce creating the Czech and Slovak Republics or the formal exit of Greenland from the EU (when its status altered to that of a dependency of Denmark) offer no real insights. As Sampson (2017: 163) observes, Brexit is not just about undoing a trading arrangement: it 'raises questions about the future stability of the EU and the extent to which further globalization is inevitable'.

Second, Brexit is beset by uncertainty about what outcome to expect. In contrast to accession to an entity such as the EU, when the parameters governing trade and regulatory terms (after any transitional period) are clear, many different outcomes for the UK are conceivable. It could be a new, but still close, economic relationship or no different from any other 'third country'. Although there has been a proliferation of research on the costs and benefits of different potential outcomes (for an overview, see Campos, 2019), it has not resulted in any sort of consensus on the optimal way forward. On the contrary, at the time of writing, most conceivable options remain on the table.

The third is political: Brexit has proved to be a policy fiasco in several respects, not least the seeming inability of the UK body politic either to frame the terms of the policy debate or to achieve successive negotiating objectives. Initial attempts by the Cameron government to obtain concessions on the terms of the UK's membership of the EU failed to mollify ardent euro-sceptics. Red lines set out by Theresa May in the early stages of withdrawal negotiations were progressively erased, yet the resulting withdrawal deal proved to be so unpopular that that it was rejected three times by the House of Commons. After Boris Johnson became Prime Minister, 'no-deal' became a viable option, despite the compelling evidence of the economic damage it would cause and the political risks.

Europe, as many have observed, has already ended the political careers of the last four Conservative Prime Ministers and has become a progressively more toxic determinant of the country's political direction. Brexit, as the culmination of a long saga intended to clarify the future of the UK in Europe has, instead, descended into a morass of indecision, recrimination and disarray. On any reasonable interpretation, this is a failure, be it of decision-making, politics, national deliberation or policy.

Complementing these policy challenges is a further one about how to conceptualise Brexit, prompting questions about the appropriate means of analysing its economic impact. Plainly, there is much more to EU membership than the trade regime, with the implication that while an assessment rooted in the economics of trade integration is necessary, it cannot be sufficient. Disentangling the UK from the EU will involve rethinking the approaches to labour mobility, regulation and regional balance. In addition to recasting the trade and investment regimes, spatial and industrial policies will have to be reconfigured. As Armstrong (2018) notes, regulatory alignment between the UK and the EU will be close in the immediate 
aftermath of Brexit, but the UK will face awkward choices about its future regulatory and divergence could well occur.

For the economics profession, tricky questions arise about how to feed into politicallycharged policy debates, how to balance the positive and the normative, and how to counter misleading claims (Begg, 2017). The tension here is that analysis of the costs and benefits of a policy choice is, or ought to be, of critical importance, yet can be relegated to a minor role if over-politicised. Findings from the British Election Study ${ }^{2}$ shed light on why the economy mattered, yet was not decisive: very few people voted 'leave' to improve the economy and very few voted 'remain' to reduce immigration. Instead, the fight was about which of these issues was more important. Yet the notion of trade-off, so fundamental to economic assessments, has been subsumed beneath deeply polarised statements.

The assertion - roundly condemned by former Prime Minister, David Cameron (2019) from Michael Gove, one of the most prominent pro-Brexit cabinet Ministers, that the country had had enough of experts and the welcome it received illustrates the concern. Indeed, throughout the Brexit saga, economic claims and counter-claims have abounded in justifying one or other stance. The soundness of the analysis behind the material used has varied hugely, with some contributions more open than others to challenge on methodological grounds, and some arguably little more than propaganda.

This article examines how economic narratives have affected the diverse failings around Brexit, drawing on a number of instances of the interplay between economic analysis and policy development. The next section explores how to conceptualise Brexit, drawing on literatures on economics and the causes of policy failure. Subsequent sections look, respectively, at the policy debates and the resulting confusions around five key dimensions of Brexit: the prospect of 'no-deal'; trade, the short-term, the longer-term impact and the public finances. The concluding part of the paper revisits how economics as a discipline can feed into debates around a major constitutional shift such as Brexit, focusing specifically on how to balance objective analysis, credibility of assumptions and choice of scenarios, and the inevitable political 'spin' imparted by those who use the underlying research.

\section{Conceptualising Brexit}

Leaving the European Union, an entity which intrudes on so many facets of the economic and social life of a country, is a complicated process. For the UK, the simple binary choice of 'in' or 'out' has proved to be inadequate, and has seen a succession of questionable economic analyses and policy misjudgements. Brexit has occurred over several stages of political decision: the referendum, the development of the negotiating position and, in the light of the many parliamentary votes against the withdrawal deal or aimed at forestalling

\footnotetext{
${ }^{2}$ https://www.britishelectionstudy.com/bes-findings/what-mattered-most-to-you-when-deciding-how-tovote-in-the-eu-referendum/\#.XLcliDBKiHs
} 
'no-deal', the contest between Parliament and the government. Much still remains to be resolved as the future UK-EU relationship evolves and it is striking how little attention has been paid in the fractious debate about the terms of withdrawal to the complexities of negotiating a future economic partnership. Moreover, Brexit is multi-layered: it comprises trade deals, regulatory models, future financial arrangements and so on, each of which has given rise to differing kinds of policy challenges.

In assessing Brexit, the underlying contention put forward in this article is that economic analysis, as a key component of the evidence base needed for informed choices and for framing the policy choices (Schön and Rein, 1994), was, and continues to be, systematically undermined. This leads to the paradox of an information gap, yet mistrust of the means of filling the gap. What is also striking from the early skirmishes - even before the calling of the 2016 referendum - is the persistence of the phenomenon.

Some messages have been clear and consistent. There will be costs for both sides as explained in academic work by, among others, Belke and Gros (2017) and Felbermayr et al. (2018), as well as in a client briefing by Goldman Sachs ${ }^{3}$, but they will be proportionally much higher for the UK, although estimates of the respective magnitudes vary depending on the methodologies employed. A 'no-deal' hard Brexit will be more damaging for both sides than a cooperative, soft Brexit, but very uneven in its incidence on different EU member states (Vandenbussche, 2019).

Equally, some of the headline economic claims were deliberately exaggerated in a way that responsible policy-makers could reasonably have been expected to avoid. Yet the many policy failures results in part from conflicting views about what Brexit is meant to deliver and evident tensions between objectives. Although there is a risk of bias from inappropriate assumptions and methods in any exercise investigating a politically contentious issue, especially when the tools of the economics trade are pushed beyond their usual range, the lack of separation between soundly-based, speculative and partisan contributions has diminished the debate. This has been aggravated by the propensity of political actors, at times, to misrepresent even the best-researched findings by selective use of data or downright mendacity. Andrew Tyrie MP, who chaired the House of Commons Treasury Committee, was forthright in a press release launching a report on the costs and benefits of leaving the EU.

"The arms race of ever more lurid claims and counter-claims made by both the leave and remain sides is not just confusing the public. It is impoverishing political debate. Today is the first day of the main campaign. It needs to begin with an amnesty on misleading, and at times bogus, claims. The public are thoroughly fed up with them. The public are right" (House of Commons Treasury Committee, 2016).

\footnotetext{
${ }^{3}$ https://uk.reuters.com/article/uk-britain-eu-goldmansachs/brexit-has-cost-britain-nearly-2-5-percent-ofgdp-goldman-sachs-idUKKCN1RD1T8
} 
In addition, a complex, constitutional change cannot easily be reduced to assessments of success or failure, effectiveness, efficiency or value for money, or other standard evaluation criteria. As Bovens and 't Hart (2016) argue, what constitutes a policy fiasco (or success) depends on the framing of the issue under examination and the perceptions of different stakeholders. Perceptions of the outcome of the policy are likely to differ markedly, not least between those who see themselves as winners and losers from it. Drawing on earlier work, they also distinguish between what they call the 'programmatic' and 'political' dimensions of a policy. The former relates to the facts associated with a policy, focusing on whether planned outputs were delivered or outcomes achieved. The 'political', in their words 'pertains to the world of impressions: lived experiences, stories, frames, counterframes, heroes and villains' (Bovens and 't Hart, 2016: 656). It is about reputation, accountability and control of the narrative, and can be significantly shaped by specific developments or interpretations. Where there is a disjunction between the programmatic and the political, it is hard to reach a reasoned verdict.

\section{Economic narratives}

A challenge is to identify what is distinct about the economics of Brexit that has allowed apparently objective facts and analyses to be contorted so much in the policy debates. One answer lies in terminology: forecasts, predictions and 'what-if' scenarios are very different analytic tools, but have been conflated in a manner inimical to sound judgement. Another concerns simplifying assumptions, unavoidably necessary for complex economic modelling, yet too poorly explained to those who exploit the findings. Then there is selective use of data - leaving aside outright mendacity - with protagonists plucking a figure from a range without spelling out the breadth and import of the range, or using unconventional means of expressing a value, such as income loss per household, instead of the more usual 'per capita'.

How, then, did economic factors affect the process at different stages? The mutual exclusivity of claims suggests framing as a crucial explanation for the Brexit debacle (Schön and Rein, 1994).The government position in the 2016 referendum was to achieve an endorsement of continued EU membership. The central argument put forward by the government was that leaving the EU would be damaging to the UK economy, a stance endorsed by the other mainstream political parties, later castigated by opponents as 'project fear'. Given the referendum outcome, the policy can be adjudged to have failed and the unsuccessful resort to warnings of economic damage was a crucial factor in the failure.

Second, the conduct of the withdrawal negotiations was predicated on achieving a deal that would minimise the economic damage of leaving while respecting a number of 'red lines'. Several of these were economic propositions with implications for what deal could be struck, such as leaving the customs union and the single market or substantially cutting UK payments to the EU. Quite rapidly, the UK position was dismissed as 'cakeism' - expecting to have the cake and eat it - also known as cherry-picking. 
Third, much of the agonising about the future relationship between the UK and the EU turns on the costs and benefits of underlying economic models. However, the over-arching message from all but a minority of economic studies has been remarkably consistent: the more distant the economic relationship between the UK and the EU, the greater the adverse impact on the UK economy is likely to be (summarised by Tetlow and Stojanovic, 2018).

A fourth illustration was the so-called 'divorce' bill which went from the EU can 'go whistle' (Boris Johnson, replying to an MP in the House of Commons in 2017) and a more sober analysis that there is no obligation (House of Lords, 2017), to an agreement to pay some $€ 40-50$ billion. While the amount was enshrined in the withdrawal agreement and is derived from calculations of UK obligations, there are voices still arguing that the UK can renege on these payments. Not to have certainty about so vast an amount of tax-payers' money is worrying.

Selective use of data plucked from studies, usually peppered with careful warnings about assumptions or the robustness of the findings which are conveniently ignored, is one means by which the economic messages have been distorted. A good example is the claim, put forward in a Treasury press release two months ahead of the referendum ${ }^{4}$, that 'Britain will be worse off by $£ 4,300$ a year if Britain votes to leave the European Union'. In what was claimed to be a 'rigorous and objective economic analysis', the headline figure is, on the one hand, just one from a range of estimates yet is presented as 'the' pivotal government stance. On the other, it is an unusual unit (the household) which both creates ambiguity about what is being referred to, because few will be aware what the average number of persons per household is, and inflates the perceived cost compared with the more conventional 'per person' measure.

\section{Media portrayal of the economics}

Media representations of the economics of Brexit also have an influence. The Press, in particular, repeatedly seized on economic analyses, using them in a confrontational way, to accentuate policy tensions over Europe. This has been part of a long-run shift towards hostility to the EU. As Daddow (2012: 1219) claims, much of the British media has 'been on a journey between 1973 and the present from permissive consensus to destructive dissent'. The claim that Brexit would free $£ 350$ million per week to spend on health policy also illustrates media shortcomings. Despite ample material debunking the claim, including from the UK Statistics Authority (the independent body charged with UK statistics), the claim was never effectively contradicted in the media. Yet a letter from Andrew Dilnot, its chair, was explicit ${ }^{5}$ :

\footnotetext{
${ }^{4}$ https://www.gov.uk/government/news/hm-treasury-analysis-shows-leaving-eu-would-cost-britishhouseholds-4300-per-year

${ }^{5}$ https://www.statisticsauthority.gov.uk/wp-content/uploads/2016/04/Letter-from-Sir-Andrew-Dilnot-toNorman-Lamb-MP-210416.pdf
}

6 | P a g e 
"Without further explanation I consider these statements to be potentially misleading. Given the high level of public interest in this debate it is important that official statistics are used accurately, with important limitations or caveats clearly explained. “

An article ${ }^{6}$ in The Independent (a pro-remain newspaper) reveals that just one week prior to the referendum, nearly half the voters contacted in a poll believed the claim. The article quotes Dilnot who 'said last month he was disappointed that the Brexit campaign continued to make the claim as it was "misleading and undermines trust in official statistics"'.

Even the supposedly neutral TV broadcasters were susceptible to distortion in how they interpreted their statutory obligation to assure balance, something emphasised in his memoirs by David Cameron (2019) who refers to a confusion between objectivity and balance. An example is a $\mathrm{BBC}$ report $^{7}$ on an IMF analysis of the UK economy, published just days before the referendum). It provides a summary of the IMF scenarios (while giving the most attention to the most negative) and offers a reasonably balanced piece by a BBC journalist. However, the only comment from an economist included in the article, attacking the whole basis of the IMF report, is from Patrick Minford, one of the very small group of Economists for Brexit. There is no counter-vailing comment from any mainstream economist, implicitly portraying the IMF as the pro-Remain voice.

\section{Economic assessments of Brexit}

The main analytic challenge in assessing Brexit lies in establishing what would have happened had the UK chosen to remain in the EU. Most approaches involve the use of economic models, the most complex of which are largely impenetrable to most users of the research in the political or media worlds. In particular, the necessary simplifying assumptions, limitations of data and methodological approach are too readily ignored. Macroeconomic forecasts of the sort routinely published by many agencies, among which some of the best-known emanate from the Bank of England, the OECD, the European Commission and the Office for Budget Responsibility, are the least problematic, to the extent that even partisan users in the policy communities understand their role in estimating how the economy will evolve in the short-term. In the Brexit context, forecasts generated prior to the referendum, for example, provided benchmarks for how the economy performed subsequently, enabling users of the data to infer what changed. In the light of some of the more lurid claims and counter-claims, it is intriguing to note that in the second semester of 2016, the economy performed pretty well as expected by the main forecasting bodies in their pre-referendum exercises.

\footnotetext{
${ }^{6}$ https://www.independent.co.uk/news/uk/politics/nearly-half-of-britons-believe-vote-leaves-false-350million-a-week-to-the-eu-claim-a7085016.html

${ }^{7}$ https://www.bbc.co.uk/news/business-36561720 
Models used to construct scenarios of what might happen under different forms of Brexit proved to be much more controversial in the policy debates. Even though their 'what if?' character is well understood by the economics profession, scenarios were too readily interpreted as forecasts in much of the public debate. As a result, their underlying purpose of elucidating what would happen if a particular path were followed, then identifying potential policy responses likely to mitigate adverse effects and reinforce positive ones was prone to be traduced. For example, warnings by the Bank of England about worst-case outcomes elicited headlines such as (The Times) 'House prices would crash by a third in no-deal Brexit, says Mark Carney' ${ }^{8}$, and (BBC web-site) 'Brexit: Carney warns no-deal could see house prices plunge ${ }^{\prime 9}$. In both articles, the presentation is more nuanced, but when subsequent work by the Bank yielded less dramatic headlines, the inclination was to portray what had been said previously as scare-mongering, casting doubt on the Bank's credibility.

Variants on gravity models became the principal mainstream approach (for example: Ebell, 2016; Dhingra et al., 2016 and 2017; Felbermayr et al., 2018), and were widely applied to assess Brexit, both in the short-term and in longer-term scenarios of how the economy will respond. As explained by Chaney (2018), it is self-evident why the size of a partner country matters, but harder to explain why distance does, although he offers a number of theoretical explanations. Intuitively, as well as conceptually, transport costs, regulatory alignment and cultural affinities are part of the story. Supply-chains are also part of the gravity story because with just-in-time production, proximity and a lack of border obstacles are considerations.

As many authors have shown, the empirical evidence is compelling. In the words of Tony Venables, one of the UK's leading trade specialists: the gravity approach 'is not a theory or model or law, but a fact. The negative effect of distance on trade is enormous. For example, the UK trades about 8 times more with France and Germany than with Japan which has a similar sized economy but is 8 times farther away'. ${ }^{10}$ Critics, such as Gudgin et al. (2018), nevertheless cast doubt on gravity models and argue, further, that they have been inappropriately applied in analysing Brexit. Their alternative estimates find a lower impact of a hard Brexit.

The 'doppelganger' method adopted by Born et al. (2019) tries to circumvent the difficulty of clashes of assumptions by comparing the trajectory of the economy of interest to a group of peers. Choosing the peer group is done by an algorithm which selects comparator countries and weights them, thereby avoiding any bias introduced by the researchers in selecting the appropriate peers. Because the doppelganger is not (or at least not significantly) affected by the policy decision (Brexit), any divergence between the constructed comparator and the actual performance of the UK can be attributed to the

\footnotetext{
${ }^{8} \mathrm{https://www.thetimes.co.uk/article/house-prices-would-plummet-in-no-deal-brexit-says-carney-csgr9j0hi}$

9 https://www.bbc.co.uk/news/business-45516678

10 https://www.pwc.co.uk/government-public-sector/assets/documents/pwc-the-gravity-model.pdf 
policy decision. The work of Born et al and Springford (2019) reaffirms the growing economic costs to the UK to date and thus before Brexit proper.

The role of economic analysis has been both central to and contested in examining different aspects of Brexit. These are now elaborated, starting with the prospect of 'no-deal'.

\section{What if there were "no-deal'?}

With increased worries about a 'no-deal' Brexit, the lack of clarity about what it entails is surprising. In the first instance, it means an exit from the EU without agreement on each other's citizens' rights, a financial settlement or how to guarantee no hard border on the island of Ireland. The withdrawal deal agreed under Theresa May, running to 585 pages but rejected thrice by the House of Commons would have settled these three dossiers and paved the way for a deal on a future relationship, but 'no-deal' mutated into a combination of these and a new trade regime based on the UK trading on the same basis as any other country lacking a special arrangement.

There is no doubt 'WTO terms' is a viable option, because the UK is a member of the organisation in its own right as well as through the EU. However, much of the UK's trade with the rest of the world is governed by agreements struck by the EU on behalf of all 28 Member States. Some of these agreements might easily be translated into terms for a UK no longer part of the EU, but there are no certainties. Nor is there an unambiguous definition of 'WTO terms', according to an explainer published by the UK in a Changing Europe (2018) think-tank: 'trading on WTO terms alone is the default position for WTO members, but in practice none does it without additional agreements'. For example, the UK already has over 100 specific agreements with the US, its largest single trading partner, going beyond basic WTO terms.

What is clear is that no deal would result in the UK facing tariffs on exports to the EU and having to impose tariffs on imports arriving from the EU. For many products, these tariffs are not that high, but for certain key industries, such as automobiles and agri-food, they are substantial. Regulatory provisions would also be relevant, because countries generally want to ensure certain standards, safety for example, for imported products and services.

While the potential costs of 'no-deal' have been extensively examined, the policy responses to mitigate or alleviate these costs have been tentative and limited in scope. The costs, for example as detailed by the Bank of England (2018) and the UK in a Changing Europe (2019) The UK government has provided for a range of measures, leading the Bank of England ${ }^{11}$ to scale down its estimates of the worst-case impact, albeit still projecting a fall of $5.5 \%$ in GDP in a worst-case scenario (down from a fall of $8 \%$ estimated previously). His explanation is

\footnotetext{
${ }^{11}$ Testimony by Mark Carney to the House of Commons Treasury Committee, $4^{\text {th }}$ September 2019; accompanying letter available at https://www.bankofengland.co.uk/-/media/boe/files/letter/2019/governorletter-to-chair-of-tsc-re-updated-brexitscenarios.pdf?la=en\&hash=2E567C985959FCF2D80A4F803A7D17392E2855DE
} 
that preparations made by the government to mitigate the adverse consequences improved matters. These new estimates are consistent with the leaked 'Yellowhammer' documents from the government about the state of no-deal preparations and the risks of disruption.

The leak in August, followed by the formal release by the government (after a battle with Parliament), of the dossier ${ }^{12}$ concerning the consequences of 'no-deal' reveals the extent of the potential damage. Although portrayed by the government as a 'worst-case' and with action already undertaken to mitigate some of the effects, the breadth and magnitude of the problems is striking. In particular, the risks for Northern Ireland's economy - ironically given the prominence of the demands by the Johnson government to abandon the 'backstop previously negotiated, are alarming.

In what is described in the summary document, in a rather Delphic manner, as a 'reasonable worst case', the government sets out a series of likely negative outcomes, unleavened by any positive ones. Key assumptions behind the document are that 'the relationship between the UK and the EU as a whole is unsympathetic', notwithstanding a hope 'some MS will be more understanding', and that 'public and business readiness for a no-deal will remain at a low level'. Lack of clarity on what happens next may exacerbate the problem. It is expected that smaller business will continue to be much less well prepared than their larger counterparts.

At sectoral level several difficulties are highlighted including:

- The likelihood of significant delays at the Dover-Calais border for lorries and difficulties for travellers there and at other points of entry;

- Possible shortages of medicines requiring special transport arrangements, such as temperature control or rapid delivery and not able to be stock-piled;

- Risks to the availability of veterinary medicines, accentuating the risks in the event of an outbreak of diseases;

- Restrictions on choice in food, but no overall shortages;

- Some disruption of cross-border financial services;

- Diminished rights for UK citizens, including entitlements, for example to health care, in other EU member states

- Traffic disruption in Kent;

- Substantial problems in Northern Ireland, especially acute for the agri-food sector;

- The prospect of clashes in fisheries, potentially escalating to violence and blockades;

- Tensions in an already vulnerable social care sector.

The government machine has been at pains to stress that an acceleration of preparations for 'no-deal' will ease some of these problems. The government also claims the work undertaken would be necessary if a deal is struck.

12

https://assets.publishing.service.gov.uk/government/uploads/system/uploads/attachment data/file/831199/ 20190802 Latest Yellowhammer Planning assumptions CDL.pdf 
Two comments are nevertheless warranted. First, even the lower figure from the Bank of England still amounts to a significant cost to the economy and, in other circumstances, would be political dynamite. Second, though, the mere fact of a shift in the level of the estimate reinforces the messages from pro-Brexiteers about the unreliability (and, implicitly, bias) of figures generated by experts and official bodies.

On the EU side, the latest update ${ }^{13}$ on preparations, issued on $4^{\text {th }}$ September, refers to a range of sectoral measures designed, notably, to avoid transport problems, facilitate the distribution of medicines and medical devices, and limit disruption of agriculture and fisheries. However, some of the measures in place, predicated on an earlier withdrawal by the UK, will only be of brief duration in the absence of fresh initiatives. For example, temporary regulations, agreed in April 2019, covering road freight and road passenger connectivity are due to expire at the end of 2019, prompting the Commission to initiate an extension of the applicability of the regulations. Similarly, air transport is vulnerable to EU rules on ownership structure. In principle, these sorts of problems can be managed by muddling-through, but they highlight the complexity of coping with no-deal.

Budgetary matters could be more problematic. The Commission notes the possibility that the UK could abruptly cease paying into the EU budget. If so, UK beneficiaries would no longer be eligible for EU spending, and some contracts might have to be terminated. Again, a temporary measure already in place would be extended to limit disruption, but it is contingent on the UK continuing to pay, thereby touching on one of the most contentious issues in the UK debate on EU membership. Indeed, Boris Johnson insisted several times during the fractious House of Commons debates in early September 2019 on the $f 250$ million cost per week of delay in completing the UK exit.

The Commission also proposes using the European Union Solidarity Fund (EUSF, an instrument for compensating member states or regions severely affected by natural disasters) and the European Globalisation Adjustment Fund (EGF, used to mitigate the effects of major firm closures) to mitigate economic costs triggered by international competition. Both would be difficult, but would also offer false reassurance. The EUSF is governed by a regulation specifying it be used only for natural disasters and there have been occasions when applications have been rejected because they did not relate to such a disaster, sets a high threshold for the damage incurred, yet has an annual budgetary ceiling of just $€ 600$ million and typically offers contributions measured in tens of millions (Bachtler et al., 2019). The resources of the EGF are even smaller, payments are subject to strict conditions and its total outlays since its inception have averaged under $€ 60$ billion per year. It is, therefore, hard to see how it could make a meaningful difference, implying these are sticking-plaster remedies.

${ }^{13}$ https://eur-lex.europa.eu/legal-content/EN/TXT/PDF/?uri=CELEX\%3A52019DC0394 
According to a study by Vandenbussche (2019) for the Flanders government, Belgium would be among the worst affected by a no-deal Brexit (with the most pronounced effect on the Flanders region), along with the UK's other closest neighbours, Ireland and the Netherlands. By contrast, the effects on most of the countries of central and eastern Europe would be small. Despite the importance of the UK for many German exporters, the impact of a hard Brexit on Germany would be relatively muted.

Of greater concern is how WTO terms would affect supply chains. According to the car industry trade body, the SMMT, a finished car exported from the UK contains parts likely to have crossed the UK-EU border multiple times in the manufacturing process. Their worries are countered by pro-Brexit bodies (for example Brexit Central ${ }^{14}$ ) who dismiss them as further resort to 'project fear'. There are also arcane rules about how much local content there needs to be in a product to allow it to be subject to a preferential tariff or regulatory regime. 'Diagonal cumulation' - the concept used to determine what trade regime applies to something exported from country $A$ to country $B$ using inputs from country $C-$ is not exactly a familiar term, even to those debating WTO terms. But as country A outside the EU, exporting to country $B$ inside it, the UK would be subject to less advantageous parameters.

Three main implications emerge from this discussion. First, the debate has been conducted on simplistic terms and the policy-makers leading it can be considered to have - to put it politely - glossed over the complications. Contrary to the image portrayed, the second is that moving from EU membership to WTO terms will be a highly disruptive and timeconsuming exercise. In this respect, an under-played facet of Brexit is that 'no deal' is very different from 'status quo'; indeed, it would have the biggest disruptive effect. Third, and arguably most alarming, there is great uncertainty about the trade regime likely to emerge and a paucity of discussion of the advantages and drawbacks of different options.

\section{Trade deal}

Much the most discussed - and contested - economic subject associated with Brexit is the future of trade, both between the UK and the EU, and the UK and other parts of the world. Options, such as trading on World Trade Organisation (WTO) terms have been bandied around with very little understanding of what they entail, while the distinctive characteristics of different types of trade have been scant attention. The UK is an exporter of goods (subject to a plethora of international agreements, including EU and WTO membership), services of different sorts and a growing share of intermediate products and services as part of supply chains and networks.

In a paper looking in detail at the likely trade consequences of Brexit - which, the authors concede, does not 'feature labor or capital mobility' - Felbermayr et al (2018: 30) model Brexit as the reverse of trade integration. They confirm the 'lose-lose' character of any Brexit scenario and find that 'small EU27 countries with very close trade ties to the UK, such

${ }^{14}$ https://brexitcentral.com/dont-believe-car-industrys-prophecies-brexit-doom/ 
as Ireland, Luxembourg, and Malta, lose even more than the UK itself'. Their findings also cast doubt on the proposition that the UK can compensate for Brexit through new trade deals with the rest of the world, although proponents of the latter view would, no doubt, put forward a counter-argument about failing to understand dynamics. What is striking about some of the estimates of trade effects is just how wide the range is, depending on different assumptions and the scenarios presented - for an overview, see Lawless and Morgenroth (2019).

With most of the discussion around membership (or not) of a (sometimes 'the') customs union or a free trade deal, only trade in goods would be covered, and many of the more detailed aspects of trade rules associated with how to determine from where any good originates (rules of origin) are glossed-over. In the great majority of trade deals, there are no explicit provisions for traded services - after all, there is no such thing as a tariff on a service. Instead, what affects trade in services is a combination of the regulatory regime affecting doing business and the freedom of the persons providing the service to do so outside their home countries.

Services make up some $80 \%$ of the UK economy and, although less orientated to exports than manufactures, still represent a major source of foreign earnings for the UK. Indeed, the growth of services as a proportion - now on a par with industrial exports - of UK foreign earnings has been striking, yet apart from the attention afforded the City of London, prone to be overlooked in the discussion of the future UK-EU relationship.

Trading on WTO terms, in practice, is far from straightforward either conceptually or as a description of how WTO members function. The notion of most favoured nation (MFN) requires countries to extend to all WTO members the terms it offers to a particular partner, with exemptions for more comprehensive arrangements such as the EU or NAFTA, as well as bilateral deals, such as the recently concluded EU-Japan deal. No major economy trades on 'pure' WTO terms and there are complex linkages derived from EU deals with other countries which could affect future UK market access.

Among the many estimates of likely trade effects of Brexit, there is a quite extensive range, but detailed work illustrates the likely orders of magnitude. Thus, using a fine disaggregation of trade (5200 products), Lawless and Morgenroth (2019) estimate there would be a $30 \%$ fall in EU exports to the UK. This would translate into a $2 \%$ fall in world trade. However, Ireland and Belgium would be hit especially hard, losing $4 \%$ and $3.1 \%$ of their total exports, respectively. UK export to the EU would fall by $22 \%$, but because the latter is a much bigger market, the effect on the UK would be much greater, leading to a fall in exports of $9.8 \%$.

Some pro-Brexit analyses (Economists for Free Trade, 2018) suggest there would be an opportunity for the UK to decide its own regulatory regime and, particularly, to cut costly checks, thereby benefitting consumers. The UK might be comfortable easing market access for, say, the US and Canada, but would be under an obligation to offer the same terms to 
others with less trustworthy systems. Chlorinated chicken might be the least of the problems. The impact on producers and consumers alike could therefore be pronounced. The cost of inspections, certification and longer warehousing could offset any reduction in EU-related regulatory costs. When the case was being put, with strong backing from the Thatcher government, for the single market during the 1980s, a key argument was to curb redundant controls and duplication of certification: WTO terms could see their return.

Brexit could also have consequences for EU27 trade policy, potentially reinforcing a recent trend for the EU to favour bilateral over multilateral deals; recent examples include Japan Vietnam. It has been argued that the UK was one of the more prominent voices for global Europe, implying a more protectionist stance after Brexit, although De Ville and Siles Brügge (2019) are unconvinced.

\section{The short-term economic impact}

Economic analysis of the short-term consequences of Brexit was extensive (for an overview, see Campos, 2019), though often controversial, partly because of the propensity of politicians to make unwarranted claims, but also because very little effort went into explaining the nature of the research undertaken. Work to develop scenarios was often interpreted as firm predictions, while figures were selectively plucked (and often repackaged) from multiple sources without regard to the compatibility of underlying assumptions. Audiences lacked the capacity to interpret findings subject to nuance and significant caveats, and there were also methodological challenges for the research community about how to assess the prospective impact of Brexit. Not the least of these is where to put the turning-point: the referendum vote, the triggering of Article 50, the twoyear deadline for exit or the actual exit. In addition, some of the key economic variables cannot readily be measured. All sides agree Brexit-related uncertainty is a phenomenon adversely affecting the economy - clearly an increasing concern during the post-referendum period - but there is no simple indicator to monitor it or its impact.

The main narrative contest around the short-term impact of Brexit was the juxtaposition of the Treasury projections (HM Treasury, 2016), issued one month prior to the referendum, and the economic indicators in the quarters following it. In summary, the Treasury set out two scenarios referred to as 'shock' and 'severe shock'. Both projected alarming consequences summed up in this statement:

"a vote to leave would cause an immediate and profound economic shock creating instability and uncertainty which would be compounded by the complex and interdependent negotiations that would follow".

The detail of the Treasury 'shock' scenario, let alone the more severe one, was alarming. A 'vote to leave would result in a recession, a spike in inflation and a rise in unemployment' [p.8], with every region affected and an increase of half a million in unemployment; the Pound would fall by $12 \%$; and there would be a jump in inflation. 
The Treasury study also refers to 'downside risks' which could accentuate the adverse effects, leading it to a stark conclusion: 'a vote to leave the EU would result in a marked deterioration in economic prosperity and security. This is based on a widely-accepted approach, and is supported by the effects of uncertainty already evident in financial markets and the real economy'. Moreover, the study was validated by independent experts and (distorted) figures derived from it were used by the Chancellor in the referendum campaign.

Although one overlooked assumption in the study was that article 50 would be triggered immediately, rather than a good nine months later, and was predicated on no policy reaction (such as the slight easing of monetary policy in August 2016) to mitigate the Brexit shock, the report was widely interpreted as a prediction. It consequently induced much gloating from leave supporters when the UK economy showed no sign of faltering in the second semester of 2016. Not only was it the fastest growing of the G7 economies, but also performed broadly in line with forecasts from the spring of 2016 assuming a 'remain' vote. In addition, the UK labour market remains robust: unemployment has fallen in nearly every month since the referendum and the headline total of employment has continued to rise.

The repercussions of this flawed effort to influence public opinion have continued to influence sentiment about how to appraise Brexit because it became the accepted wisdom that the Treasury (and, more generally, the economic profession) had 'got it wrong'. Ironically, after article 50 was triggered, the UK growth rate did deteriorate (although never coming close to the recession foreseen by the Treasury), becoming the slowest in the G7 in 2017 and the slower growth has persisted in recent quarters. Various explanations can be put forward to explain the absence of a shock to the economy. A fall in the exchange rate did happen, helping net exports (including by encouraging UK residents to takes their holidays at home - 'staycations'), there was (limited) action by macroeconomic policymakers to stimulate the economy and global conditions were favourable.

But on any reasonable interpretation, the Treasury analysis was excessively pessimistic, while the Economists For Brexit (now Economists for Free Trade ${ }^{15}$ ) on the 'leave' side were far too sanguine. A retrospective review by Chris Giles of the Financial Times ${ }^{16}$ found the mainstream forecasters to have been accurate before and, more so, after the referendum, He concludes that the 'lesson is simple: listen to economists, but not to those peddling a political line'. In addition, evidence on the effects of the Brexit decision is now becoming available. De Lyon and Dhingra (2019), for instance, draw attention to a range of negative effects alongside lower growth: low productivity growth, a fall-off in inward investment, flat-lining consumer purchasing power and lacklustre export growth. None is dramatic on its own, but the aggregate effect is likely to be damaging.

\footnotetext{
${ }^{15} \mathrm{https} / / / \mathrm{www}$. economistsforfreetrade.com/

${ }_{16} 14^{\text {th }}$ March 2019 https://www.ft.com/content/534e108a-4651-11e9-b168-96a37d002cd3
} 
Other evidence of the negative effect of Brexit on the economy tells a similar story. The most recent doppelganger exercise by Born at al. (2019) now puts the loss at $2.1 \%$ of GDP, while Springford (2019) finds it to be a little higher. Born et al. also expect the loss to exceed $4 \%$ of GDP by the end of 2020 . The example of the public finances suggests lessons are needed about transparency and honesty, not least about the trade-off between different determinants. Over-simplification of the budgetary arithmetic could have been avoided by responsible politicians.

\section{The public finances}

How Brexit will affect the public finances featured prominently in the referendum campaign because of the very high profile claim that the UK would gain by ending, or substantially cutting, its payments into the EU budget. In addition to the rebuke from the Statistics Authority noted above, the 'leave' claim was repeatedly debunked in academic work (for example, Begg, 2016; Emerson et al., 2016) and was condemned in a report of the House of Commons Treasury Committee (2016). As the Treasury Committee (para. 32) noted, the claim is 'highly misleading to the electorate'.

The underlying facts are well-known and relatively easily explained, prompting the obvious question of why the figure was able to achieve such traction. It is therefore worth settingout how it was arrived at. The EU budget is roughly one percentage point of the Union's GDP, and the starting point for what each Member State is expected to pay is the equivalent share of its national GDP. However, the various 'corrections' (rebates) introduced over the years reduce the amount certain net contributors - especially the UK - have to pay, with the cost falling on the remaining Member States. The amount countries remit to the EU (the expression used in the campaigns was 'send to Brussels') is after deduction of the rebate.

There are, however, much greater imbalances in how much Member States receive from the budget to fund EU policies in their jurisdiction, especially relating to agriculture and regional development. Broadly, this results in poorer Member States being net recipients while richer ones are net contributors, although the vagaries of the main EU spending programmes means the relationship is not exact. The UK receives comparatively little from EU spending programmes.

A partial explanation for the durability of the claim can be deduced from the details of how the numbers are presented in different documents. Table 1, reproduced from the HM Treasury (2015) presentation of UK budgetary transactions with the EU, shows the ex-ante UK gross payment and the rebate, but then has a less intuitive figure for UK receipts channelled through the public sector. The latter includes, notably, direct payments from Brussels to farmers, but excludes EU spending paid directly to the private sector, for example in the form of research grants. These are instead mentioned in a footnote with an estimated value. 
It can immediately be seen that, in round numbers, the gross payment to the EU in 2014 of $£ 18.8$ billion, divided by 52 weeks is indeed roughly $£ 350$ million per week. But the rebate of $£ 4.4$ billion in the same year represents $£ 85$ million per week, meaning the money 'sent to Brussels' was $\mathrm{f} 265$ million per week. Even without having to deduct spending from the EU budget in the UK to arrive a still lower net contribution, the $£ 350$ million headline figure (which, it should be noted, continued to be cited well beyond the referendum) was unambiguously wrong. The Vote Leave protagonists, as their evidence given to the 2016 House of Commons Treasury Committee Inquiry shows, relied instead on Balance of Payments Statistics published by the ONS, in the 'Pink Book' for $2016{ }^{17}$.

Table $1 \quad$ UK Treasury figures on the UK contributions to the EU budget

\begin{tabular}{|c|c|c|c|c|c|c|c|}
\hline & & & & & & & E million \\
\hline & $\begin{array}{r}2009 \\
\text { Outturn }\end{array}$ & $\begin{array}{r}2010 \\
\text { Outturn }\end{array}$ & $\begin{array}{r}2011 \\
\text { Outturn }\end{array}$ & $\begin{array}{r}2012 \\
\text { Outturn }\end{array}$ & $\begin{array}{r}2013 \\
\text { Outturn }\end{array}$ & $\begin{array}{r}2014 \\
\text { Outturn }\end{array}$ & $\begin{array}{r}2015 \\
\text { Estimated } \\
\text { Outturn }\end{array}$ \\
\hline $\begin{array}{l}\text { Gross } \\
\text { Payments }{ }^{2}\end{array}$ & 14,129 & 15,197 & 15,357 & 15,746 & 18,135 & 18,777 & 17,779 \\
\hline Less: UK rebate & $-5,392$ & $-3,047$ & $-3,143$ & $-3,110$ & $-3,674$ & $-4,416$ & $-4,861$ \\
\hline $\begin{array}{l}\text { Less: Public } \\
\text { sector receipts }\end{array}$ & $-4,401$ & $-4,768$ & $-4,132$ & $-4,169$ & $-3,996$ & $-4,576$ & $-4,445$ \\
\hline $\begin{array}{l}\text { Net } \\
\text { contributions } \\
\text { to EU Budget }\end{array}$ & 4,336 & 7,382 & 8,082 & 8,467 & 10,465 & 9,785 & 8,473 \\
\hline \multicolumn{8}{|c|}{ 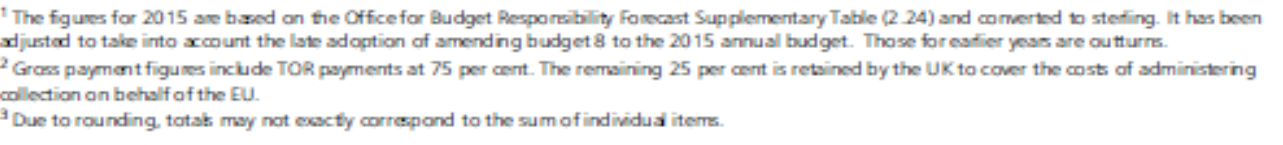 } \\
\hline \multicolumn{8}{|c|}{ Source: Office for Budget Responsibility and HM Treasury } \\
\hline
\end{tabular}

More broadly, the effect of Brexit on the UK's public finances will depend on opposing factors. There will, first, unambiguously be a gain for the UK from lowering its payments into the EU budget. Although the longstanding British rebate has meant that the UK generally makes the smallest gross contribution (as a proportion of GDP) of any Member State to 'Brussels', it is still a substantial sum, reaching $€ 15-17$ billion in recent years. EU spending in the UK, principally for direct payments to farmers, provides some offset, but the net contribution is still of the order of $€ 10-12$ billion per annum. Long-term, this is a potential saving to British tax-payers of the order of $0.4 \%$ of GDP.

However, if the UK economy grows more slowly as a result of Brexit, there is likely to be deterioration in the public finances. Tax revenue as a proportion of GDP has been around $37 \%$ in recent years which, for an economy of roughly $£ 2$ billion means that every percentage point of additional GDP translates into revenue of $£ 7.4$ billion. According to the Office for Budget Responsibility (2018), the annual deterioration since the 2016 referendum, has been greater than the net payment to the EU, although much of this is attributable to building in slower productivity growth. Using the doppelganger approach, Springford (2019)

${ }^{17}$ file:///H:/UK\%20Balance\%20of\%20Payments,\%20The\%20Pink\%20Book\%202017.pdf 
finds the deterioration has now reached $£ 19$ billion per annum, exceeding the windfall gain claimed by the 'leave' campaigns. It is important to stress, too, that these are likely to be permanent losses, because it would take above-average growth for a number of years for the short-term hit to the economy to be reversed.

The question from the perspective of economic narratives is whether the manner in which the information is published was a contributory factor. In all these examples of presentations of EU budgetary flows to and from the UK, there are valid explanation rooted in the accounting or statistical norms adopted for why they are as they are. However, they manifestly open the gate to misunderstanding and misrepresentation. There is also again a question of how certain statements frame the subsequent narrative. In setting out her negotiation objectives in her January 2017 Lancaster House speech ${ }^{18}$, Theresa May set the tone by saying: 'the days of Britain making vast contributions to the European Union every year will end', creating strong expectations of improved finances.

Thus, in the balance of payments statistics, recording the rebate (albeit a different amount from what the Treasury reports) separately from the ex-ante (though hypothetical) gross payment is consistent with the formal accounting methodology, but unlike the Treasury table where the two figures are adjacent, they are in different tables. The gross payment is shown as a debit and the rebate as a credit. This separation between the figures leads to confusion for the uninitiated while facilitating misuse of the information by the mendacious.

Understanding the wider impact of a policy choice on the public finances is also vital. Given the broad consensus noted above on the likely negative effects of Brexit on growth, the indirect macroeconomic effect of Brexit on the public finances is expected to be negative. Further negative effects can be foreseen from a financial settlement with the EU (probably spread over several years), the transitional costs of implementing Brexit (preparations for 'no deal' or one-off costs of establishing new administrative capabilities, for example for customs' checks), and from recurrent costs of public administration tasks such as certification or, again, customs controls. Add in the likelihood that the UK will want still to be involved, even in a limited manner, in certain EU policies, such as research, and it becomes clear Brexit's impact on the public finances cannot be reduced to the saving on EU budget payments.

\section{The many economic trade-offs of Brexit affecting the longer-term}

As noted in an Institute for Government overview of studies on Brexit, 'economic theory and evidence provide a much stronger basis for making long-term projections than for making short-term forecasts (Tetlow and Stojanovic, 2018)'. Only one of the many studies surveyed anticipated any macroeconomic gains from Brexit, although the survey also notes the considerable range of negative outcomes, depending on the assumptions underlying the

\footnotetext{
${ }^{18}$ https://www.gov.uk/government/speeches/the-governments-negotiating-objectives-for-exiting-the-eu-pmspeech
} 
research. The one outlier, by Economists for Free Trade ${ }^{19}$, derives much of the projected gain from opportunities for de-regulation, an assumption heavily criticised by other contributors (such as Sampson et al. 2016).

EU membership or any alternative economic relationship between the UK and the EU cannot, however, easily be reduced to a single measure of well-being capturing the aggregate net economic benefits. Put another way, it involves reconciliation of diverse effects and, if any attempt is made to aggregate them, judgements about the weights to apply to each effect. The latter are necessarily subjective.

A government internal assessment, only published at the insistence of the House of Commons Brexit Committee ${ }^{20}$, concluded that the UK economy would be worst off under WTO terms, somewhat better if it had a free trade agreement with the EU and least affected if it had a closer, EEA style arrangement. These findings largely accord with the great bulk of academic studies.

Beyond headline economic growth, it is, nevertheless, worth itemising the relevant economic determinants and considering who they affect and how. Among the most significant are public finances, market access, the form of regulation, research policy, and the spatial and sectoral distribution of economic activity. Politically sensitive, if economically less significant, areas associated with EU policy include agriculture (around 1\% of GDP, and $1.5 \%$ of employment) and fisheries (barely $0.1 \%$ of UK GDP, but locally quite concentrated). The UK fishing industry has been especially hostile to the EU's Common Fisheries Policy, mainly because of dissatisfaction with the access enjoyed to the rich British waters by boats from other EU Member States.

According to a House of Commons briefing ${ }^{21}$, 'direct Common Agricultural Policy (CAP) subsidies can make up to $80 \%$ of a UK farmer's income', with the implication that the sector will need a comparable regime if it is not to face severe upheaval. The government has already promised to maintain the subsidy level for the expected duration of the current Parliament, up 2022.The EU is by far the biggest export market, taking over $60 \%$ of the total and well above the proportion of manufacturing exports. A recent report from the NFU puts the direct exports of food and drink in 2017 at $£ 22$ billion, but makes the more extravagant claim that agri-food business is worth $£ 122$ billion, some $6 \%$ of GDP. ${ }^{22}$

How then might economic analysis have been more subtle and capable of exerting a more nuanced influence? A simple answer is to look at the different dimensions of the economic

\footnotetext{
${ }^{19}$ https://www.economistsforfreetrade.com/wp-content/uploads/2018/03/Alternative-Brexit-EconomicAnalysis-Final-2-Mar-18.pdf

${ }^{20}$ https://www.parliament.uk/documents/commons-committees/Exiting-the-European-Union/17-19/CrossWhitehall-briefing/EU-Exit-Analysis-Cross-Whitehall-Briefing.pdf

${ }^{21}$ https://researchbriefings.parliament.uk/ResearchBriefing/Summary/CBP-8218

22 https://www.nfuonline.com/cross-sector/farm-business/economic-intelligence/economic-intelligence-must$\mathrm{read} / \mathrm{nfu}$-guide-state-of-the-farming-economy/
} 
relationship and to consider how from the perspective of the UK as a whole they would be affected by Brexit. Table 2 presents assessments of some of the main elements of such a cost- benefit calculus, drawing on published material and informal discussions between the author and a range of relevant experts. The data are presented on a six point scale ranging from three 'thumbs-up' to three 'thumbs-down'.

While manifestly open to challenge, these (subjective) assessments provide some sense of the scale of likely impacts. Thus, there will be savings on payments to the EU - as noted above, but if the focus is on the overall effect on public finances, the savings will be more than negated by the costs from the harder variants of Brexit. The table also demonstrates the diversity of likely effects, emphasising the need to acknowledge the difficult trade-offs involved. If, however, one criterion, such as respect for the 2016 result, is deemed to be lexicographically paramount, then all other considerations become largely irrelevant.

Table 2 The diverse merits and drawbacks of Brexit

\begin{tabular}{|c|c|c|c|c|c|}
\hline CRITERION & Hard Brexit & $\begin{array}{l}\text { May's } \\
\text { deal }\end{array}$ & Norway & $\begin{array}{l}\text { Customs } \\
\text { Union }\end{array}$ & Remain \\
\hline $\begin{array}{l}\text { Impact on the } \\
\text { economy }\end{array}$ & 8 & 98 & हो & हो & की \\
\hline $\begin{array}{l}\text { Control of free } \\
\text { movement }\end{array}$ & की & (1) & 5 & है & 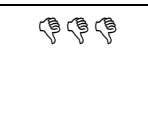 \\
\hline Payments to the EU & हो हो हो & (1) & 58 & ?? & 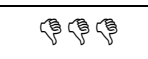 \\
\hline $\begin{array}{l}\text { Total effect on public } \\
\text { finances }\end{array}$ & 4 & 但 & 家 & 宣 & ही \\
\hline $\begin{array}{l}\text { Voice in setting } \\
\text { regulations }\end{array}$ & है & 但 & 58 & 但 & हो \\
\hline Nationally & हो & हो & 战 & हो & हो \\
\hline Internationally & 58 & S & ) & S & हो \\
\hline $\begin{array}{l}\text { No hard border in } \\
\text { Ireland }\end{array}$ & (1) & हो & 48 & की & की \\
\hline $\begin{array}{l}\text { Own fisheries and } \\
\text { agriculture policy }\end{array}$ & क्री है। & हो & हो हो & 要 & 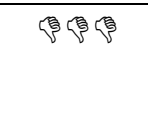 \\
\hline $\begin{array}{l}\text { Respect for } 2016 \\
\text { vote }\end{array}$ & की बी है & s) & 9 & $\%$ & $P 96$ \\
\hline
\end{tabular}

Source: own elaboration 


\section{Conclusions}

Brexit has been hard to analyse because it is beset by uncertainties, has few (if any) direct or relevant precedents, and seems to defy conventional political economy reasoning in how the anticipated economic consequences affect citizens' stances on it. More than three years after the referendum, there is no clarity about what sort of future relationship the UK will have with the EU, nor even of how negotiations will proceed, as proceed they must eventually. While there is broad agreement that Brexit will entail costs for both sides, especially in the event of a 'no-deal' withdrawal, and special issues of journals examining the question have proliferated, there is no consensus on whether the likely costs will be temporary or permanent, limited or severe, nor of which interests will be worst affected.

Nevertheless, it is undeniable that Brexit as a policy process has been far from smooth or comfortable for the two sides and it can be argued that citizens have been let down by the political machinations and inability of decision-makers to agree on the way forward. What sort of lessons might, then, be learned? A first, direct set could be for any Member State contemplating secession from the Union, with the UK experience serving as a manual for how not to do it. Second, there are lessons about how to negotiate in a context in which significant economic costs and benefits are at stake. Third, there are lessons about the economy, stupid' as a narrative for policy.

There is some evidence of a disjunction between the dominant narratives of economic damage and the more marginalised counter-narratives suggesting any economic costs will be short-lived at worst. There is, too, already evidence of other member states recognising the economic costs facing the UK and of a toning down of rhetoric about further 'xits', even in the pronouncements of euro-sceptical parties. This is unsurprising given the progressive understanding of the breadth of economic arrangements to be disentangled, especially regulatory provisions.

Economics has manifestly been challenged by the whole Brexit process because there has been no real parallel on which to draw. 'Dis-integration' cannot sensibly be regarded as the mirror-image of the economics of integration, even if some of the methodological foundations of any assessment are similar. However, the centrality of economic effects in arriving at a judgement on the overall consequences of Brexit and the costs and benefits of different configurations of the UK-EU relationship require sound input. This is a dilemma for the economics profession: how to be relevant and engaged while remaining objective.

The dilemma is especially tricky when the tools of the trade include contestable assumptions and unavoidable simplifications as underpinnings for models used to generate forecasts and projections. As a result, it is easy for confusion to arise about whether it is the methodologies or the findings that are being disputed. Misuse of statistics, perhaps based on ignorance, lack of attention to caveats about the reliability of estimates, or overt misrepresentation of 'facts' exacerbate the problem. 
The central message from mainstream economic analyses is, though, both plausible and negative: the greater the barriers between the UK and the EU27, the bigger the relative losses for the UK economy. More worrying for the British economy is the interplay between the direct effects of Brexit and longer run trends. Lower potential growth could, for example, become lower still if Brexit deters skilled immigrants or growth enhancing inward investment, or disrupts supply-chains.

Above all, economic analysts have to be alert to the risks inherent in contributing to controversial decisions when the prospect of badly conceived policy coincides with highlycharged political stances. They arguably have to assume that findings will be cherry-picked or stripped of caveats, and be prepared to counter distorted claims. However, as the (ultimately ineffectual) example of the statement by the Statistics Authority on the $£ 350$ million per week budget windfall demonstrates, correcting an entrenched misrepresentation is far from easy.

As Khrushchev put it: 'economics is a subject that does not greatly respect one's wishes'.

\section{References}

Armstrong. K.A. (2018) 'Regulatory alignment and divergence after Brexit' Journal of European Public Policy 25.8, 1099-17

Bachtler, J., Begg, I., Ferry, M. and Ogilvie, J. (2019) Ex-post Evaluation of the European Union Solidarity Fund, Report to DG Regio of the European Commission, https://ec.europa.eu/regional policy/sources/docgener/evaluation/pdf/eusf 2002 2016/e usf 20022016 final en.pdf

Bank of England (2018)

Begg, I. (2016) 'The EU budget and UK contribution', National Institute Economic Review No. 236, 39-47

Begg, I. (2017) 'Making sense of the costs and benefits of Brexit: challenges for economists' Atlantic Economic Journal 45(3), 299-315

Belke, A. and Gros, D. (2017) 'The economic impact of Brexit: evidence from modelling free trade agreements' Ruhr Economic Paper No. 700 http://www.rwiessen.de/media/content/pages/publikationen/ruhr-economic-papers/rep 17 700.pdf

Born, B., Müller, G., Schularick, M. and Sedlacek, P. (2019) ' $£ 350$ million per week: the output cost of the Brexit vote' Voxeu, https://voxeu.org/article/300-million-week-outputcost-brexit-vote 
Bovens, M. and 't Hart, P. (2016) 'Revisiting the study of policy failures' Journal of European Public Policy 23(5), 653-66

Cameron, D. (2019) For the Record, London: William Collins

Campos, N. (2019) 'The economics of Brexit' The New Palgrave Dictionary of Economics Online https://link.springer.com/referenceworkentry/10.1057/978-1-349-95121-5 3079-1

Chaney. T. (2018) 'The gravity equation in international trade: an explanation', Journal of Political Economy 126(1), 150-77

Daddow, O. (2012) 'The UK Media and 'Europe': From Permissive Consensus to Destructive Dissent' International Affairs 88(6), 1219-36

De Lyon, J. and Dhingra. S. (2019) 'Economic performance since the EU referendum', Centre for Economic Performance Paper CEPBREXIT14, http://cep.Ise.ac.uk/pubs/download/brexit14.pdf

De Ville, F. and Siles-Brügge, G. (2019) 'The impact of Brexit on EU trade policy' Politics and Governance 7(3), 7-18

Dhingra S, Ottaviano G, Sampson T and Van Reenen J (2016) 'The impact of Brexit on foreign investment in the UK', Centre for Economic Performance Paper CEPBREXITO3, http://cep.Ise.ac.uk/pubs/download/brexit03.pdf

Dhingra S, Huang, H., Ottaviano G, Pessoa, J.P., Sampson T and Van Reenen J (2017) 'The costs and benefits of leaving the EU: trade effects' Centre for Economic Performance Discussion Paper 1478, http://cep.lse.ac.uk/pubs/download/dp1478.pdf

Ebell, M. (2016) 'Assessing the impact of trade agreements on trade', National Institute Economic Review No. 238, R31-R42.

Economists for free trade (2018)

Emmerson, C., Johnson, P., Mitchell, I. and Phillips, D. (2016) Brexit and the UK's Public Finances, Report No. 116, London: Institute for Fiscal Studies

Felbermayr, G., Gröschl, J. and Steininger, M. (2018) 'Quantifying Brexit: from ex post to ex ante using structural gravity' CESifo Working Paper 7357, https://www.cesifo.org/DocDL/cesifo1_wp7357.pdf

Gudgin, G., Coutts, K., Gibson, N. and Buchanan, J. (2017) 'The role of gravity models in estimating the economic impact of Brexit' Centre for Business Research, University of Cambridge Working Paper No. 490 https://www.cbr.cam.ac.uk/fileadmin/user upload/centre-for-businessresearch/downloads/working-papers/wp490.pdf 
HM Government (2018) 'EU exit: long-term economic analysis' Cm 9742, https://assets.publishing.service.gov.uk/government/uploads/system/uploads/attachment data/file/760484/28 November EU Exit - Long-term economic analysis 1 .pdf

HM Treasury (2015) 'EU Finances 2015: statement on the 2015 EU Budget and measures to counter fraud and financial mismanagement', Cm 9167,

https://assets.publishing.service.gov.uk/government/uploads/system/uploads/attachment data/file/483344/EU finances 2015 final web 09122015.pdf

HM Treasury (2016) 'HM Treasury economic analysis: the immediate economic impact of leaving the $\mathrm{EU}^{\prime}, \mathrm{Cm}$ 9292,

https://assets.publishing.service.gov.uk/government/uploads/system/uploads/attachment data/file/524967/hm treasury analysis the immediate economic impact of leaving the eu web.pdf

House of Commons Treasury Committee (2016) 'The economic and financial costs and benefits of the UK's EU membership', First Report of Session 2016-17, HC 122

https://publications.parliament.uk/pa/cm201617/cmselect/cmtreasy/122/122.pdf

House of Lords European Union Committee (2017) Brexit and the EU Budget, $15^{\text {th }}$ Report of 2016-17 session, London House of Lords, https://publications.parliament.uk/pa/ld201617/ldselect/ldeucom/125/125.pdf

Howlett, M. (2012) 'The lessons of failure: learning and blame avoidance in public policy', International Political Science Review 33(5): 539-55

Lawless, M. and Morgenroth, E.L.W. (2019) 'The product and sector level impact of a hard Brexit across the EU' Contemporary Social Science 14.2, 189-207

Minford, P. (2019) 'The effects of Brexit on the UK economy' World Economy 42, 57-67 https://www.economistsforfreetrade.com/wp-content/uploads/2019/02/The-Effects-ofBrexit-on-the-UK-Economy-World-Economy-Jan-2019.pdf

Office for Budget Responsibility (2018) 'Economic and fiscal outlook' Cm 9713, https://cdn.obr.uk/EFO October-2018.pdf

Rosamond, B. (2019) 'Brexit and the politics of UK growth models' New Political Economy 24.3, https://www.tandfonline.com/doi/full/10.1080/13563467.2018.1484721

Sampson. T., Dhingra, S., Ottaviano, G. and Van Reenen, J. (2016) 'Economists for Brexit: a crtique', Centre for Economic Performance Paper CEPBREXITO6, http://cep.Ise.ac.uk/pubs/download/brexit06.pdf

Sampson, T. (2017) 'Brexit; the economics of international dis-integration' Journal of Economic Perspectives 31.4, 163-84 
Schön, D.A. and Rein, M. (1994) Frame Reflection Toward the Resolution of Intractable Policy Controversies, New York: Basic Books.

Springford, J. (2019) 'The cost of Brexit to December 2018', Centre for European Reform Insight, March 2019, London: CER

https://www.cer.eu/sites/default/files/insight JS 29.3.19.pdf

Tetlow, G. and Stojanovic, A. (2018) 'Understanding the economic impact of Brexit', Institute for Government, https://www.instituteforgovernment.org.uk/sites/default/files/publications/2018\%20lfG\%2 0\%20Brexit\%20impact\%20\%5Bfinal\%20for\%20web\%5D.pdf

UK in a Changing Europe (2018) 'What would "trading on WTO terms" mean for the UK?', http://ukandeu.ac.uk/wp-content/uploads/2018/12/What-would-trading-on-WTO-termsmean-Long-Guide.pdf

UK in a Changing Europe (2019) 'No deal Brexit: issues, impact, implications' https://ukandeu.ac.uk/wp-content/uploads/2019/09/No-deal-Brexit-issues-impacts-andimplications-1.pdf

Vandenbussche, H. (2019) 'Sector-level analysis of the effects of Brexit on the EU 28' Report prepared for Flanders Department of Foreign Affairs, Belgium, https://www.fdfa.be/sites/default/files/atoms/files/Brexit\%20impact\%20study\%202019.pdf 